\title{
An examination of Melody's identities, contexts, and learning in a US science classroom: implications for science education of Asian transnational students
}

\author{
Minjung Ryu
}

Correspondence: mryu@purdue.edu Department of Curriculum and Instruction, Department of Chemistry, Purdue University, $100 \mathrm{~N}$. University Street, West Lafayette 47907, IN, USA

\begin{abstract}
This study examines how Melody, a Korean transnational girl in the US, participates in high school AP (Advanced Placement) biology class, engages in identity work, and learns science. Melody was a daughter of a gireogi family (a transnational family separated for educational purposes), living with her mother and brother in the US. The recent increase of transnational educational migration among Asian students and the importance of identity in understanding students' learning and participation motivated this study. I define identity as a type of personhood and view that it is always performed and negotiated by individuals in their social lives. Drawing on ethnographic data collected in Melody's AP Biology class, I will show Melody constructed identities as a non-participant, limited English-proficient student and incompetent biology learner. Her identity construction was influenced by the meso level contexts (e.g., school, classroom) and personal contexts (e.g., gireogi family contexts). Yet, Melody constantly negotiated with these contexts to re-figure her identities to be more conducive to her biology learning and to enhance her classroom participation. This study demonstrates how individual students in the US, while coming from a stereotypically successful ethnic group, experience their life contexts and explore possibilities for learning and being in different ways. Implications include how researchers and teachers should pay attention to individual differences and contexts in order to better facilitate their science learning and classroom participation. I will also provide implications for education in countries that send gireogi families and transnational students.
\end{abstract}

Keywords: Asian transnational students, Identity, Gireogi family

To access the executive summary of this paper in Korean, please check the supplemental materials associated with this article by clicking on this link (Additional file 1).

\section{Introduction}

In recent years, Asian immigrants have comprised one of the fastest-growing immigrant populations in the US (Pew Research Center 2012). Despite the heterogeneity and diversity in Asians' educational attainment (Covarrubias and Liou 2014; Paik et al. 2014), Asian students are often lumped together and are believed to be successful high achievers, especially in the field of science and mathematics (Lee 2009; Trytten et al. 2012). Recent social changes in Korea and China add another layer of complexity to

(C) 2016 Ryu. Open Access This article is distributed under the terms of the Creative Commons Attribution 4.0 International License (http://creativecommons.org/licenses/by/4.0/), which permits unrestricted use, distribution, and reproduction in any medium, provided you give appropriate credit to the original author(s) and the source, provide a link to the Creative Commons license, and indicate if changes were made. 
the prevalent monolithic image of Asians as a successful model minority. Since the late 1990s, the number of Korean K-12 school students who have moved to Englishspeaking countries has increased, and this trend, which had been limited to a only a small number of wealthy families, has rapidly expanded among Korean middle class families (Finch and Kim 2012). China also has sent an increasing number of socioeconomically and geographically diverse students abroad, many of whom come to the US and settle in various locations across the country (Portes and Zhou 2012). While several studies have examined diverse characteristics of Asian students and challenges that they face in US contexts, little is known about these students' lived experiences in science classrooms. In this study, I aim to fill this gap in the literature by investigating the lived experiences of Melody, a Korean high school girl from a transnational family (gireogi ${ }^{1}$ family), in her Advanced Placement (AP) ${ }^{2}$ biology class. In particular, I will examine her identities in the contexts of school, her AP Biology classroom, and in her family.

In the following section, I provide context for Melody's experiences with transnational educational migration. Afterwards, I define identity and the related constructs of agency and context based on a theoretical tradition that emphasizes discursive performativity and social construction of identity (e.g., Butler 1990; Holland et al. 1998; Wortham 2006). Next I introduce my research questions and research methods and I discuss the study's findings to provide implications for expanding our understanding of and teaching for Asian transnational students in science classrooms.

\section{Gireogi family and transnational educational migration}

In the past few decades, an increasing number of Asian school-aged children have crossed international borders to pursue education in English-speaking countries, such as the US, Canada, Australia, and New Zealand. Within Asia, Singapore and Hong Kong have become new destination countries for many Chinese and Korean families as these countries offer English-medium educations and are relatively cheaper and nearer than other English speaking countries (Huang and Yeoh 2011). While some children migrate alone or with both parents, others go with only one of their parents. In these separated families, mothers often accompany the children to the destination country while the fathers remain in the home country to work and provide financial support. In many cases, the father can only visit the mother and children a few times a year. This gendered form of transnational ${ }^{3}$ family separation is referred to as a gireogi family in Korea and an astronaut family in Hong Kong, Taiwan, and China (Waters 2012). The term gireogi refers to migratory wild geese that migrate a long distance. Both terms are used to refer to either working fathers who remain in their home country or families who have left their home countries to support their children's pursuit of educational degrees and English learning in a new country. In many cases, these families maintain this life style for years until the children enter college.

Recent studies have focused on the neoliberal reorganization of the global economy as a critical factor for explaining why these transnational families are emerging. Researchers see transnational migration as a response to neoliberal influences in Asian countries where public education policies and private sector industry increasingly emphasize a need for proficiency in English to be successful (Chang 2006; Lee 2010b). Along with competence in English, experiences and educational degrees from universities in English speaking countries, especially in North America, have become important forms of social capital necessary for securing job appointments and promotions in 
Asian countries. The changing landscape of the global economy has pushed many Asian families to separate for improved educational opportunities abroad. The Asian financial crisis in the late 1990s resulted in a rapid increase in transnational migration among middle class families, but this was particularly true for Korean families as Korea's finance and business sectors, and consequently opportunities in job markets, were severely affected (Finch and Kim 2012; Cho 2005; Koo 2007; Park 2009).

When Asian families commit to transnational separation, they do so with the hope that their children will accumulate cultural capital, such as English proficiency, social capital, such as cosmopolitan experiences and networking opportunities, and symbolic capital, such as diplomas from prestigious colleges, which will help them attain positions in competitive prospective job markets. Waters (2012), however, points out how this form of educational migration reproduces social inequality rather than providing social mobility because it is only the families that already have a certain level of social, economic, and cultural capital that can successfully engage in transnational migration. As a result, this practice reproduces existing social economic hierarchies in the sending countries. Even in cases where middle class families manage to afford transnational educational migration, the children of upper class families benefit more from their parents' financial stability and social networks by receiving more support for English learning, academic development, and for coping with stress (Lew 2006). By contrast, many middle and lower middle class families experience downward social mobility upon their relocation to destination countries (Huang and Yeoh 2011). At the same time, this increasing number of transnational families contributes to the reproduction of linguistic and cultural hegemony of English as a dominant global language (Lee 2010a; Guo and Beckett 2007).

Transnational families assert that they so value their children's education that they are willing to sacrifice their marital relationship and other social dimensions of family life in order to improve their children's English proficiency and to support their children to attain diplomas from prestigious colleges (Lee 2010a). However, children of transnationally separated families report they face various psychological, linguistic, and academic challenges, and the families face many challenges to maintain family ties while being separated for extended periods (Shin et al. 2014; Yeh 2003). Mothers in separated families experience an extreme level of stress, emotional instability, and struggles in everyday life attributable to social isolation, financial hardship, and institutionalized constraints for transnational wives (Huang and Yeoh 2011). Finally, because the families have sacrificed so much for their children's education, these students face incredible pressure to become proficient in English and to be successful academically and socially.

These issues warrant in-depth research to understand how transnational family migration influences the ways in which these children experience their learning environments and how they participate in school and in science. By examining a girl from a gireogi family as she negotiates identities and learns science in an AP Biology class in the US, this study seeks to contribute to research efforts to better understand Asian students from transnational families.

\section{Theoretical framework}

Identity has become a critical analytic tool for understanding students' learning and engagement in science, or failure thereof (Brown et al. 2005; Calabrese Barton et al. 2013; Carlone et al. 2014; Kozoll and Osborne 2004; Rahm and Moore 2015). Working from 
this tradition, rather than assuming that individuals learn objective knowledge about scientific facts and the process of scientific inquiry, scholars are concerned about social and interpersonal interactions through which students learn science and develop identities in science. Beyond mere cognitive explanations of science learning, aspects of learners' affect (e.g., interests, attitudes, and motivation toward science) are highlighted as essential factors that facilitate or impede students' learning.

In particular, identity has been employed in explaining why school science education does not adequately support learning of students from certain racial, linguistic, socioeconomic, and gender backgrounds. For instance, in many school settings, students who are successful at science are regarded as being a "geek" or a "nerd" and engagement in science is associated with masculinity (Archer et al. 2010). Additionally, science learning is often related to high-status social identity, such as being smart (Olitsky 2007). These models of identity (Wortham 2006) may conflict with the ways in which some students view themselves and are perceived by others. Both female students and students who are from racial groups that are historically underrepresented in science may have socially constructed identities that conflict with the science identities that would be favorable for learning and engagement. Brickhouse and Potter (2001) showed that when two young women of color were positioned as being less capable in school science than their peers, this positioning impeded the development of their science learning and their development identities in science. This study and others have found that for minority students, science learning requires a particular kind of negotiation between a student's social and ethnic identities and a student's science learning identities (Kozoll and Osborne 2004; Brickhouse and Potter 2001; Kahveci et al. 2008; Malone and Barabino 2009).

Previous studies that have documented interconnections between students' multiple identities and science learning and participation provide a rationale for this study. Given how complex the US education setting is, it is particularly important for researchers and educators to have a more nuanced understanding about how Asian students construct their science identities and consider the implications of these identities for science learning. Theoretically, I draw on the perspective that foregrounds the discursive construction, performativity, and flexibility and malleability of identity (Butler 1990; Holland et al. 1998; Wortham 2006). This perspective suggests how agency and context shape individuals' identity work. Building on the literature, I discuss how I view identity, agency, and context.

\section{Identity}

I define identity as a type (or label, kind) of personhood, including the ways in which an individual and surrounding people view the person. As Butler (1990) argues, I view that identity is a doing itself and is "performatively constituted by the very 'expressions' that are said to be its results" (p. 34). In every interactional moment, people decide how and what to speak, what gesture and facial expression to make, and what not to speak and do. When a particular way of speaking, acting, and interacting is consistently recognized as a certain kind, the person is identified as that kind of person.

Someone may argue that there are natural, static identities determined by nature, such as nationality and ethnicity, which are different from an identity of a smart individual or a science person. Butler (1990) problematizes the simple distinction between nature and 
culture by refuting the distinction between sex, determined by genes and body parts that have been traditionally considered as nature and biology, and gender, socially and culturally constructed ways of thinking, speaking, and acting like a woman and man. According to Butler, sex itself is a gendered construct in that scientific and biological discourses have determined sex as binary categories and individuals are always under cultural compulsion to be identified and become one by acting like other people who are categorized as the same. There is a cultural framework that recognizes different body types as two distinct, incompatible categories of sex. Thus, identities that we often perceive as born with and natural are indeed socially, culturally, and politically constructed.

In order to construct an identity, an individual should interact with other people, who are also doers, and other doers through social interactions should evaluate the deeds of the focal individual. In the words of Holland et al. (1998), identity is "an outcome of living in, through, and around the cultural forms practiced in social life" (p. 8) and develops through dialectic and dialogic interactions with the environment, cultural artifacts, and surrounding people. In social interactions, people are discursively positioned, such as by overt mention of someone's identity, implications and presuppositions, evaluative orientations to ongoing talks and participants, and linguistic structures associated with a particular identity (Bucholtz and Hall 2005). It is important to note that identities do not emerge from one interactional event, but through participating in multiple events (Wortham 2006). That is, people develop identities only through repeating patterns of behavior and discourse, and being repeatedly recognized for the patterns of doing and speaking by surrounding people.

Wortham (2006) suggests that identity construction always requires certain models that define a type of person. This is because people always speak, act, and interact in a particular way, but not every bit contributes to indexing and constructing their identities. For a particular pattern of doing to be developed as an identity, participants in a social setting should recognize a relevant identity model that describes how the identity is enacted and represented in social interactions. Some identity models circulate macroscopically in a society or country, while others can emerge and be negotiated in local settings that are spatially and temporally bounded, such as in an ethnic group, age group, academic discipline, local community, or neighborhood (Wortham 2006; Bucholtz and Hall 2005; Ochs 1993).

Finally, I point out that identity is not achieved "as if there were a telos that governs the process of acculturation and construction," nor does the process of identity construction end at any point in time (Butler 1990, p. 45). People continuously and constantly develop identities as they encounter new people in new interactional settings and interact with them. While fluid, identities provide or constrain one's behavior and talk. This is because individuals choose what and how to speak, act, and interact, sometimes consciously and at other times not fully consciously, partially based on who they are and how they are viewed (Wetherell 2007). By examining enacted practices and talk of a transnational high school student as she participates in different activities in various social contexts, I explore how this student engaged in identity work in school and AP Biology class.

\section{Agency}

In this cognitive and social process of identity work, agency plays a key role. Duranti (2004) defines agency as "the property of those entities (1) that have some degree of control over their own behavior, (2) whose actions in the world affect other entities 
(and sometimes their own), and (3) whose actions are the object of evaluation" (p. 453). Agency is closely related, but not identical to, intentionality or consciousness: "Control over" one's own behavior does not always mean directionality and consciousness. In many social practices, deeds made without consciousness exert power to affect other entities and/or affect others in ways in which the doer does not anticipate. Yet, even in these situations we should assume that the doer still practices agency since "the possibility of having acted otherwise" (Duranti 2004, p. 454) is the evidence of the doer's agency (see also, Bucholtz and Hall 2005). Simply put, speaking, acting, and interacting is agentive in its own right. Duranti calls it "inevitability of agency" and "either the goal or the result of a person's being in-the-world" (p. 468).

What connects agency and identity is performance-acting, speaking, and interacting-in social settings. Individuals agentively make intimate and immediate sense of an interactional setting, negotiate what is possible at the moment, and pursue what they want within the constraints. That is, while not seen, people always enact their agency to perform in a particular way in social settings, which is what surrounding people observe and use to identify each other as being a particular kind of person. This conceptualization allows us to view individuals as agentive doers who constantly interact with given environments, make sense of them based on prior experiences and knowledge, and "accept, negotiate, and resist the subject-positions available to them" (Campbell 2005, p. 4). This perspective thus encourages moving beyond assuming the dualism between structure and agency or viewing agency as a static personal trait that some people have more of while others have less. Rather, enactment of agency is an integral part of one's living and being. In this regard, my analytic foci are on the how and what of agency-how individuals make sense of the contexts in which they live and what they decide to do based on their sense-making-rather than how much or how strong enactment of agency must be in order to overcome structures and constraints.

\section{Context}

As another key construct in understanding identity, I discuss context. Goodwin and Duranti (1992) define context as "a frame that surrounds the event being examined and provides resources for its appropriate interpretation" (p. 3). Thus, context includes, but is not limited to, physical materials, people, ideologies, the composition of and relationships among people, experiences, and memories. Context also spans across multiple time and geographical scales (Wortham 2006; Anderson 2009). In this perspective, context is a resource or a patchwork of resources that participants in the focal event actively and dynamically engage in and connect with in respect to the focal event. Context is not simply a background that is separable from a focal event but is deeply interrelated with it to the extent that the boundary drawn between the two may be blurred. This implies that context is relevant to individual participants in social settings rather than an outside analyst and that context is shaped and reshaped by participants as they make sense of any given situation and act on it.

Building on this perspective, I define contexts in identity construction as resources on which individuals draw (1) to recognize possibilities available to themselves, (2) to determine what to enact among those possibilities, and (3) to interpret others' identities enacted in an interactional moment. To categorize different kinds of contexts that are important in identity construction, I suggest four dimensions of contexts, macro, meso, 
micro, and personal. Macro-level contexts are resources that are culturally, historically, and socio-politically established and that impact a broad group of people. Meso-level contexts include relevant resources in a geographically and temporally bounded setting such as classrooms, schools, and neighborhoods in which members share a certain degree of interactional history and/or institutionalized memories. Meso-level contexts are nested in macro-level contexts, yet they do not conform to the macro-level contexts, but instead rearticulate them with specific details that emerge from local practices of or challenges to macro-level ideologies. Micro-level contexts are the contingency of a specific interactional setting and moment (Wortham 2006; Anderson 2009). Various aspects of micro moments of interaction and dynamic contingency (e.g., what participants say and do in social interactions) influence how individuals speak, act, and interact and, in turn, what identities they construct. Finally, individuals also bring personal contexts to a particular interactional setting. Personal contexts concern the environment and resources that are relevant to an individual, such as a person's social history and physical and symbolic assets. The attention to personal experiences and interactional history offers an insight into how people in the same interactional setting speak, act, and interact differently as well as interpret the situation differently (Spencer 1999).

These four dimensions of contexts are not separate categories but highly intertwined and influential on each other. In this study, I particularly focus on identifying and understanding the meso-level (e.g., school, classroom) and personal (e.g., family) contexts that influenced Melody's identity construction in an AP Biology class. Focusing on these two contexts helps recognize differences between people of a particular cultural group situated in different local settings as well as individual differences between those people in the same local setting. By shedding light on the intimate contexts of Asian transnational students' experiences as science learners, I aim to provide a nuanced understanding of a Korean transnational student's science identity.

\section{Research questions}

Based on this theoretical understanding on identity, agency, and context, I ask:

- What identities does a Korean transnational girl performatively and agentively construct and negotiate with respect to biology, her AP Biology class, and the people around her in a US high school?

- What contexts (e.g., school, classroom, family) shape the ways in which she constructed and negotiated these identities?

\section{Methods \\ Data collection \\ Participant selection}

The data for this study come from a 1-year-long ethnographic research project I conducted at Parkview High School in 2010-2011 school year. Parkview High is located in Parkview City, a suburban area in a mid-Atlantic state in the US. Parkview City is populated by a large number of recent Korean immigrants, Korean ethnic restaurants, and businesses owned by Korean immigrants and Korean-Americans. In the year before my data collection, roughly $15 \%$ of students enrolled at Parkview High reported that Korean was spoken at home. In the same school year, White students accounted 
for about $41 \%$ of the students while Asian or Pacific Islanders ${ }^{4}$ accounted for $30 \%$ of the total students, followed by Hispanic (11 \%) and Black (10 \%) students. Other Asian or Pacific Islander students were primarily Chinese and Indian transnational students. Approximately $17 \%$ of the total students received free or reduced-price meals, and $13 \%$ of the students were categorized as having limited English proficiency. I conducted this ethnographic study in two AP Biology classes taught by Ms. Davis, a White woman in her mid-thirties. She had been teaching high school biology for 9 years at the time of this study. In early February 2011, Ms. Davis left the class for a maternity leave and a long-term substitute teacher named Ms. Wilson came to teach the class. Ms. Wilson is a White female retired high school biology teacher. The overarching goal of the ethnographic study was to examine Korean students' discursive participation and identity work in US science classes. The two classes contained approximately 30 students, among which roughly one third were students of Korean descent.

Overall, I interacted with and collected data from over 20 Korean students enrolled in Ms. Davis's AP Biology class. I selected Melody, a senior Korean transnational girl for a close case analysis for two reasons: richness of her data and uniqueness of her case. Melody was one of the students who were open to me and willing to share their stories and thoughts. She referred to me me as eonni, which is a term used by younger women to refer to close female friends who are a few years older than themselves while other Korean students addressed me as seonsaengnim, which means teacher. In the interviews and other informal conversations, Melody told me about various experiences in school, including her feelings and struggles. In addition, I was able to interview her mother. These rich data allowed me to understand her sense-making of contexts and identity work. I present Melody as a representative case (Yin 2003) of Korean transnational students in that she was lively and talkative outside of the classroom and reported she had been even more socially active before her migration to the US, but she was reticent and not actively participatory in class in the US (Ryu 2013). She was, however, a counterexample to the prevalent notion that Asian and Korean students are academically well performing and strong in mathematics and science. In addition, Melody was a daughter of gireogi family, which is an increasing phenomenon, but is not well known among educators in the US. These unique characteristics made her case worth analyzing closely with respect to her science learning, participation, and identity work.

\section{Classroom videorecordings}

During my fieldwork, I visited the AP biology class on a daily basis. For every visit, I observed the class, wrote extensive field notes, video- and/or audio-recorded the class, and generated student utterance maps. I installed a video camera at a front corner of the classroom to capture a wide-angle view of the classroom and placed a voice recorder on the desks to record students' conversations during group work activities. The student utterance maps were made using a Microsoft Excel spreadsheet in which I recorded the names of students who made an utterance along with corresponding time stamps of the utterance during the lesson. In most days, each class period (roughly 90 min) comprised of Ms. Davis's lecture and various group activities. While her lecture was monologic in nature, she also welcomed students' utterances such as questions, answers to her questions, and unsolicited comments. Group activities included lab 
experiments and collaborative problem solving. Outside of the classroom, I often spent time in the school's media center and cafeteria to observe students from the AP biology class in different settings and to engage in informal conversations with the students in both Korean and English.

\section{Interviews}

I interviewed over 20 Korean students, several non-Korean students, Ms. Davis, and Melody's mother. I interviewed Melody on three occasions. The first interview focused on her view of herself with respect to schooling and biology learning. I asked questions like why she decided to take AP Biology, what she thought of the class, and how and why she participated in learning activities in this class as well as in her other classes. I also explored her general affiliations with respect to science by asking what courses she had taken previously and what career she hoped to pursue in the future. The second and third interviews focused on her social lives outside of the AP Biology class (e.g., friends and after-school activities) and her migration experiences (e.g., motivations for migration and early experiences after her family's relocation to Parkview). By asking these questions, I sought to gain an insight into Melody's school and neighborhood contexts as well as her family background.

After the three interviews with her, I interviewed her mother. I designed the parent interview questions in an attempt to understand family context and how family influenced on Melody's transnational experiences. During the interview, I asked her mother how the family came to live in the US and in Parkview City, how she viewed and supported Melody's science learning and schooling, what social networks she had developed, and how she used such networks to support Melody's schooling. All interviews were video- or audio-recoded and transcribed verbatim.

\section{Data analysis}

\section{Classroom video recordings}

The analyses of classroom video/audio recordings served two purposes: analyzing the contexts that were relevant to Melody's identity work and her identity work itself within the contexts. To accomplish the first purpose, I watched the unedited classroom video recordings and wrote a summary of each lesson that focused on the content of each class, activities, and any noticeable episodes (Derry et al. 2010). After, and concurrently with, this analysis I identified episodes in which Melody displayed recognizable speech, action, or interaction. The identified episodes typically composed of a few turns of talk. I transcribed the selected episodes and analyzed what and how she spoke, acted, and interacted with surrounding people.

\section{Interviews}

I thematically analyzed the interviews with members of Parkview High. As van Manen (1990) argues, I view theme as intransitive outcomes of the researcher's sense-making as opposed to "objects one encounters at certain points or moments in a text" (p. 87, van Manen 1990). I identified blocks of data that helped answer the proposed research questions and coded them with my initial sense making. After generating the initial set of themes, I looked across the themes to identify repeating themes, closely related themes, or conflicting themes, and then generated upper level themes. Findings from 
these analyses provide readers an insight into how Parkview High and Melody's AP Biology class looked. ${ }^{5}$

The interviews with Melody and her mother were analyzed in a similar way to identify themes. In the thematic analysis of Melody's interview, I identified themes like "non-participant" and "incompetent biology learner" whereas themes from her mother's interviews included "isolation" and "demoralization." Additionally, I analyzed how Melody narrated her identities in the interviews from "a performative perspective" (Smith and Sparkes 2008). Because I do not view that individuals carry an internally coherent and static sense of self, I did not engage in interviewing and analysis of the interview data to get access to the individuals' core sense of self. Rather, as (Baker 2002) reminds us, I assumed that interviews are a part of everyday social interactions in which the interviewer and interviewee discursively engage in identity work. In this regard, Melody's identities narrated in the interviews are aspects of her identities that she decided to discursively construct in the particular moment of the interviews, which might have been invoked because of her vivid memories and/or by the interview questions or her relationship with me. Thus, in analyzing the interviews with Melody, when necessary, I conducted a line-by-line analysis to examine discursive identity construction by identifying, for instance, her discursive indexical processes and her expression of adequation with some identities or distinction from others (Bucholtz and Hall 2005).

\section{Identifying intertextuality between classroom video/audio recordings and interviews}

Analyses of the interview data and classroom video/audio data informed each other and provided emerging insights. The analysis process was not linear but iterative in that I went back and forth between the two data sources and analyses of the two. I treated Melody's identities narrated in the interviews and performed in her AP biology class as a repertoire of her identities that were performed in different social interactional contexts. To capture the rich scope of her identities, I documented in analytic notes my emerging sense of who Melody was by identifying and recording intertextual connections between the findings of the interviews and classroom recordings, which were sometimes consistent with and in other times inconsistent with or contradictory to each other. The analysis of the large scope of an ethnographic study provided a situated understanding of how Melody spoke, acted, interacted, and learned in the AP biology class.

\section{Findings}

To provide resources for readers to better understand her identities, I first describe the meso-level contexts (e.g., Parkview High, AP Biology class) and the personal contexts (e.g., family background) that were most closely relevant to her identity construction. While other dimensions of contexts (i.e., macro- and micro-level contexts) are also important, by focusing on these two dimensions of contexts, I aim to provide a new understanding of Asian transnational students' lived experiences that are often obscured when researchers focus on macro-level contexts and/or micro-level moment-to-moment analysis of classroom interactions. Following this section, I will present the identities that are most salient with respect to her biology learning and participation in class. 


\section{Meso-level context}

\section{Parkview high school}

Parkview High enrolled racially and linguistically diverse students including students of White European descent, African American and transnational African, Latino/a, Chinese, Indian, and Korean students. These racially and linguistically diverse students formed their peer cliques based on racial/ethnic and linguistic backgrounds and did not frequently interact with peers across the boundaries. This racial/ethnic and linguistic divide was visible in the school cafeteria and media center by how students chose to seat themselves. The divide was also evident in the AP Biology class. Students almost always sat in the same seats throughout the school year and the seating arrangements were bounded by proximity to co-ethnic and linguistic friends.

Moreover, Koreans at Parkview High formed two distinct categories, FOB (Fresh Off the Boat) and Twinkie (a popular cake that is yellow on the outside with a white cream center), and members of these two groups did not frequently socialize across the boundary between the two categories. Both of these terms are racial slurs ${ }^{6}$ used toward Asian transnational migrants: FOBs refer to newcomers of Asian descent whereas Twinkies refer to Asians who have lived long or were born in the US and are perceived as being "White washed." In students' words, Twinkies speak English like native speakers and act and think like (White) Americans.

At Parkview High, Twinkie-identified students cast FOBs mostly in a negative identity model. They asserted that these newcomers always speak Korean and maintain Korean culture, and that transnational students should give up Korean culture and adapt to American ways of acting and living. Twinkie-identified students thought that FOBs do not perform well in school, were aggressive, and tended to isolate themselves from other people. Because of these characterizations, many students who identified themselves as Twinkies did not want to befriend FOBs and distanced themselves from them. As a result, FOB-identified students, who had not attained the cultural and linguistic resources necessary to fully integrate into the school were marginalized by Asian American students.

This negative narrative about newcomer transnational students is also evident in the macro-level ideology that shapes US values regarding English monolingualism and the need for immigrants to fully assimilate to become an "American" (Wiley and Lukes 1996; Yoon et al. 2010). As Lee (2010a) implies, the cultural and linguistic hegemony of English may not only be a prejudice held by people living the US, but could also be held by Korean students prior to moving from Korea. Shaped by the societal level discourses about symbolic power of English and culture of Englishspeaking countries, students at Parkview, including both Koreans and non-Koreans, were stratified with regards to the English proficiency levels and perceived degree of assimilation and actively participated in the reproduction of the existing ideology.

\section{AP biology class}

Ms. Davis's instructional practices were somewhat traditional in that she gave lecture using Powerpoint slides during which students were seated and expected to take notes. While the students were frequently asked to do laboratory experiments, the AP course requires students to participate in highly structured labs that are 
designed to guide students through a particular lab procedure and path of reasoning rather than offer students opportunities for free exploration of ideas. Ms. David assigned homework assignments (e.g., readings, worksheets, essay writing) almost every class and held high standards for her students as she attempted to educate them at the level of an introductory college biology course. The class had exams once every 3 to 4 weeks, and after the exams Ms. David sometimes announced the name of students who received the highest score. She was highly regarded among fellow teachers and students for her ways of teaching and was recognized for holding high standards for students' learning.

In addition, it is noteworthy that Ms. Davis used various strategies in order to draw students' attention to her lecture, help them understand and remember complex biology ideas, and make the lecture enjoyable. For instance, she employed humor and made references to popular culture and everyday experiences that she assumed were shared by all students. These include popular television shows and movies (e.g., CSI, Little People Big World, and the Wizard of OZ), sports (e.g., basketball player Yao Ming and Andre the Giant) and activities (e.g., building a snowman or making beef stew). Drawing on these pieces of local and youth knowledge, she created analogies and mnemonics to help students understand biology content.

Employing analogy and humor, especially by drawing on students' everyday knowledge and teenage culture, is not an uncommon instructional practice (e.g., Bellocchi and Ritchie 2011; Kamberelis 2001). In particular, Ms. Davis's pedagogical strategies reflect what teacher educators' refer to as the construction of hybrid practices that connect science ideas, terminology, and knowledge with students' everyday knowledge and language use. However, Bruna (2009) argues that such pedagogical interpretation of the hybridity as a teacher's pedagogical strategy does not consider hybrid practices that are being constantly crafted by students to blend multiple ideas and discourses of home and school contexts. That is, teachergenerated hybridity are still under the teacher's control, which means that participation in this biology classroom discourse requires not only biology content knowledge, but also localized cultural knowledge that the teacher decides to bring to the classroom discourse. Kamberelis (2001) notes that not all students, particularly those who emigrated from other countries and who have not established social networks with peers born and raised in the host country, may not attain the kinds of knowledge that is needed for participating in these teacher-generated hybrid discourses. In this study, I found that such classroom practices and the racial and linguistic divide that existed among students appeared to provide unique, and challenging, contexts for Melody's identity work.

\section{Personal contexts}

Melody's family

Melody's family lived as a gireogi family. Her father was working as a doctor in Korea, and her mother, an older brother, and Melody moved to the US. Melody's mother was not employed outside of the home and her primary responsbilities were taking care of her children's education and well-being. When asked what motivated her family's migration to the US, she explained that she was concerned that her children would not do well and not be able to survive in the highly 
competitive Korean educational system and that she was tired of the arbitrariness, instability, and irrationality of Korean society. She wanted to educate her children in a country that was more consistent, stable, and rational, that had clear and straightforward methods for problem solving, and that required less competition in schooling and college admission. She expected her children would learn these values by living in what she believed to be an "advanced society." Strikingly, however, she added, "Now that I have come here, I feel like America is good and has a good system, but only for its own citizens, not for us, foreigners." Then, her eyes became watery. At this moment, which was 5 min into an hour-long interview, it became evident that she felt extremely marginalized in the US and did not feel like a member of society even though she had been living in the US for 6 years.

Throughout the interview, the most salient theme was her feeling of alienation and isolation from society. Primarily, her feeling of alienation originated from the fact that she did not speak English. Whenever she spoke English to someone, she was worried about "how much this person would be looking down on me," which made her feel like not being a member of the US society. Although she assumed that her children might feel less marginalized because they spoke English better than she did, she thought that Melody's English proficiency was not sufficient to study school subjects and to mingle socially with English speakers. She made several comparisons between the life they were living in the US and the life she believed they would have lived had they continued to remain in Korea. For example, because her own social networks and knowledge about this country were limited, she was not able to provide her children with experiences that they would have had in Korea. Parkview City did not have a good public transportation system. Because Melody did not drive, it was not easy for her to go out and meet friends, which otherwise would have been her daily routine as it is for many high school girls in Korea. She explained that Melody mostly came home after school and stayed in bed all day. She said, "I feel like three of us are banished to a small island and caught in a small jail."

Melody's mother implicitly and explicitly expressed the desire to develop more diverse social networks and her frustration at failing to do so. A few years before, Melody's mother attended an English language school where she met several Korean gireogi mothers. This school appeared to be the most important, and perhaps, only reliable social network accessible to her since moving to the US. From these Korean mothers, she gained useful information regarding her children's education and resources available to those living in the area. In addition, through the experience of learning English, she realized how hard it must be for her children to learn English and to socialize with English-speaking peers. When they first moved to the US, Melody's mother pushed her children to befriend native English-speaking children. However, as she tried to learn English herself, she realized the difficulty they faced and thus began to encourage her children to socialize with people no matter their language or race. She did not want her children to have to deal with the emotional burden of "getting demoralized and despondent among English-speaking kids" because she reasoned they must already feel discouraged in their classes by "being not good at English." Challenged by living in the US and limited with regards to her ability to provide resources for Melody to 
learn English or expand her social networks, she focused on trying to support her children emotionally and affectively. She said that it is not good to live in " $a$ foreign country" and people should live in "their own country," which Melody said in her interview as well.

Findings from the interview with Melody's mother are consistent with the experiences of mothers who moved to Singapore from China where they reported facing various social and emotional struggles (Huang and Yeoh 2011). These findings imply that family contexts and a mother's sense making and negotiation of issues in those contexts have the potential to impact on their children's learning. For example, Melody's mother made sense of her contexts of living in the US as a foreigner, which resulted in her needing to negotiate between a) having her children reach out to expand their social networks and to learn English while being emotionally challenged and demoralized and b) learning English slowly and not excelling in school but doing so from a safer, more comfortable social space with peers who support them. To ease Melody's distress, she supported her children to choose the latter option rather than forcing them to learn English and socialize more with English-speaking peers. However, when Melody and her transnational peers enacted such practices, Twinkie-identified students often interpreted such doing as "They [FOB] do not try to learn English," or they try to separate "themselves from American society." Thus, the practices supported by Melody's family in her personal contexts had the potential to position her as a marginalized group who did not try to learn English or integrate into the larger society.

\section{Melody's identities}

A close analysis of the meso-level contexts and personal contexts provides an important insight into how and why Melody constructed her identities. Here, I present Melody's identity work focusing on four aspects: a newcomer but not FOB; an incompetent biology student; an active participant and contributor in small group activities with Korean peers; and a cooperating, attentive, and quiet participant. While I acknowledge that she might have enacted various other identities, these four aspects were most salient in her biology class and relevant to her biology learning. In the sections that follow, I present Melody's identities by weaving findings from the interview data and classroom video recordings together into a storyline.

\section{A newcomer but not FOB}

Melody had two names: Melody and Min Young. She used her English name Melody when interacting with her teachers and non-Korean peers, whereas most of her Korean friends called her by her Korean name Min Young. Perhaps, her use of these two names implies an ambivalence or flexibility about how she identified herself with respect to her ethnicity. In some ways, Melody was like a teenage girl in Korea or a newcomer Korean labeled as a FOB at Parkview High. For instance, she used her Korean name, socialized with Korean speaking peers in her AP Biology class and in other areas in the school building, such as the cafeteria. The clothes she wore were similar to what other teenage girls in Korea wore (e.g., leggings, a short skirt or dress, long boots, hair pins with flowery ribbons). During lunch she used chopsticks to eat rice and Korean dishes from an insulated lunch box. 
However, Melody, although in a subtle way, resisted being classified as a FOB that drew on these static and dichotomous labels imposed on transnational students. During an interview when asked why she decided to take the AP Biology class, she explained, "All kids take AP Biology." I then requested her to clarify what "all kids" meant and she answered:

I: $\quad$ Friends, kids, did you mean your friends or students at Parkview High?

Melody: Aha, friends, I mean, all kids. It includes [my] friends, Twinkies, and other American kids because all of them take [AP Biology].

I: $\quad$ You said, friends, Twinkies, and other American kids. How do you distinguish them?

Melody: Twinkies are those who grew up in America, so that's why they are called Twinkies. Friends are Jiyeon, Eunmi, Minjoo, Heejin. American kids are just American.

I: $\quad$ Then, you are not in the Twinkie group?

Melody: ((shaking head)) Nope.

This interview excerpt implies that she was clearly aware of the social categories that divided students based on various institutionalized factors (e.g., race, immigrant status, language) and acknowledged that she tended to socialize almost exclusively with recently arrived Korean transnational students like herself. When interviewing students, many of those who categorized themselves as Twinkies referred to the recently arrived Koreans as FOBs. However, Melody did not call herself or her friends FOBs. In the above excerpt, Melody drew a contrast between her friends and Twinkies, but she still refrained from referring to her friends as FOBs. This was different from the students who had lived in the US longer and argued, sometimes proudly, their status as Twinkies. It appeared that Melody recognized the negative connotations of FOB and did not want to be called a FOB not to be associated with the negative images.

While Melody did not develop social relationships with many other students, Melody expressed her eagerness to connect with peers outside of Korean-speaking recent migrants. In the interview, she said, "Ah, only if I could speak English well, I would like to [talk to and socialize with students outside of my clique]," and "It's not good that I cannot make many friends," and pointed these out as disadvantages of living in the US and attending American schools as a Korean. Here, she strongly resisted the identity model imposed on newcomers that they do not want to socialize outside of their ethnic and linguistic group.

This analysis demonstrates her sense-making of the contexts in which she engaged. Melody, categorized as a FOB by others, felt isolated and marginalized in the school and also in the classroom. While she wanted to connect with other students, she could not do so, partly because of her limited English proficiency and partly because of her FOB identity and the marginalization of the FOB-identified students. The finding also suggests that her sense-making was similar to how her mother viewed the family's contexts as marginalized foreigners. However, she tried to re-author her identities by referring to her friends as "friends" and avoiding the FOB label and asserting that she wanted to befriend a broader group of students. Perhaps she wanted to delete her FOB identity and fit into the Twinkies group. Or, she might have been trying to create a new identity model, such as newcomers that do not have the bad traits that many people ascribed to FOBs. 


\section{An incompetent biology student who is non-participatory and a language learner}

Melody explained her academic identity with respect to the AP Biology class as being an incompetent student and a non-participant in the class. When asked to describe herself in the biology class, she started her answer with a big sigh:

Melody: Ah ((sighing)), when sitting in the class, first of all, I become despondent and demoralized because of the teacher.

I: $\quad$ Oh, okay. In what sense do you feel like that?

Melody: Well, the teacher, I don't perform really well in that class. But, you know, by nature, teachers all, every teacher likes students who perform well.

In this brief moment and throughout the entire interview with her, it became obvious that she was frustrated because she was not performing well in the class and wanted to do better. When I asked if she sometimes requested help of Ms. Davis, she answered, "The teacher, ah ((sighing)), it is hard to go to see her. It's scary." To explain why she did not ask questions of Ms. Davis, Melody said,

If I started out asking questions when I had questions from the beginning, she would have probably taught me and we would have been closer. But I haven't asked what I didn't know, and I kept not asking until now, you know. So I feel a little like, if I ask now, she may think that I am so stupid.

She had developed an identity of a non-question-asker who does not interact with the teacher or ask questions in class. She also expressed her desire to answer the teacher's questions in class by saying, "Well, when the teacher asks a question, I really want to answer. Even though I really want to answer, because I don't know the answer, I cannot answer." Classroom video and audio data and the student utterance map indicate that Melody's perception of herself was consistent with how she actually behaved and spoke in class. She did not make observable bids to ask questions or answer Ms. Davis's questions that targeted the whole class. Interviews with Ms. Davis revealed that she also had a similar observation with regards to Melody's participation and was worried about Melody's grades on exams.

Melody described herself as non-participant as well with respect to group activities:

I tried hard to do well. I really like doing stuff. With kids, I really like to lead and engage actively. Although I always want to do all the work, because there are things that I don't understand in the lab instructions, I can't do well and so I feel frustrated and stuff.

Her lack of participation and frustration seemed to be particularly strong when she had to collaborate with non-Korean students, as shown when she said, "I am not sure if I am correct. American kids, alm[ost], they all perform well. Because I could be a little wrong, that kind of stuff [annoys me]."

Ms. Davis had noticed the racial and linguistic divide that existed in her class and had hoped to regroup students to help facilitate interactions across racial and linguistic boundaries. To that end, in one class she engaged students in a jigsaw activity. For this activity, students were first asked to read different short sections 
of the book and then to join a new group where they would be responsible for explaining the section that they had read to the members of their new group. Regarding this jigsaw activity, Melody explained,

I did the part that was assigned to me. But I couldn't read it all. I had read the beginning of it. But the teacher said the latter part is more important. But I couldn't read that part. So, ((sigh)), I talked about the beginning part a little, and just told them that I didn't know. So [we] asked the teacher to teach us.

This interview excerpt shows that the time allocated for the completing the reading assignment was not long enough for Melody to read and comprehend the material. Moreover, she seemed intimidated by the fact that she could not complete the reading but was still expected to present her understanding of the reading to unfamiliar, English-speaking classmates. Her answer to my question and her sigh suggested that she was stressed about having to ask the teacher to help explain her section of the book to her peers. In another class in which Ms. Davis attempted to mix students across their cliques, Melody was assigned to a group with several English-speaking, non-Korean students. In this group, she did not talk to the group members but only observed how other students manipulated the lab materials. When her group finished the experiment, she voluntarily joined a group with a Korean girl, although they were not assigned to the same group, and collaboratively filled out the lab worksheet.

Multiple times throughout the interviews, Melody mentioned her limited English proficiency as a source of her challenges to studying biology. The advanced level biology content was difficult, and because the already difficult content is written in English, she was even more intimidated. Melody attributed her infrequent discursive participation to her limited English proficiency. Interestingly, Melody reported she was more interested in social studies-related subjects than natural science-related subjects, yet she took more science and mathematics courses than social studies. According to Melody's mother, because of her limited English proficiency, she could not and should not pursue a career in the fields that requires advanced English proficiency, such as politics, although she was talented in these subject areas. Thus, when considering what kind of course to take and career to pursue, Melody faced a conundrum of wanting to choose disciplines that were related to her genuine strengths (i.e., her interests and talent in social studies-related fields) and feeling required to choose disciplines that were related to her situational strengths (i.e., natural science that requires less advanced English proficiency).

Despite her strategic choice to select AP Biology in an attempt to mitigate her identity as an English learner, this class sometimes served as a space in which Melody's identity as a newcomer and limited English proficient student became evident and she was penalized for her shortcomings. For instance, once when Melody and her Korean speaking peers were engaging in a lively discussion, Ms. Davis chastised Melody's group to stop speaking in Korean by saying, "ladies, English, English ((a lapse of $20 \mathrm{~s})$ ) English, we are practicing our Engli:::sh ((a lapse of $20 \mathrm{~s})$ ) Ladies, English. I want you to practice your English, please." After Ms. Davis's remark, a Korean boy, who identified himself as a Twinkie, looked at Ms. Davis and laughed abruptly and loudly.

In this episode, Ms. Davis' remarks positioned Melody and her peers as non-fluent English speakers and her comments communicated this to the class. However, Ms. Davis's 
apparent attempt to have these girls to speak in English did not seem to achieve its goal as the audio data revealed that soon after Ms. Davis's comment, the students started speaking Korean again. They spoke quietly perhaps in order not to be heard by Ms. Davis. In an interview, Melody and other girls in this group said that even when teachers asked them to speak English, they still spoke in Korean. Melody explained, "We speak in English at first [when teachers tell us not to speak in Korean], but after that Korean just comes out again." Ms. Davis's demand to speak English did not encourage them to speak in English, but only discursively marked them as English learners with limited English proficiency.

Another example of how Melody's limited English proficiency impacted on her identity as an incompetent student in Biology was revealed during an episode in which Ms. Wilson, the substitute teacher was teaching the class. Melody had received a lower grade on her homework assignment than she had anticipated so she approached Ms. Wilson during class to inquire about the reason for her low grade. Later, a Korean girl in the class, who overheard the conversation, explained to me that Ms. Wilson took points off of Melody's grade due to her poor English grammar.

As shown in these examples, the AP Biology class offered a meso-level context for constructed identities as incompetent biology student, non-participatory student, and language learner student. I point out that Melody constructed these identities based on several conventional class norms and a good-student identity model that appeared to be brought to the AP biology class by both her teachers and peers. For instance, competent students attain good grades in class tests (Carlone et al. 2014), classroom participation is equated with verbal participation that can be recognized in whole class discussions (Reda 2009), and classroom conversations should occur only in the authorized language of English (Wiley and Lukes 1996). In addition, the school and classroom contexts in which students formed visible racial and linguistic group boundaries contributed to Melody's construction of identities as a non-participants and English learner.

\section{An active participant and contributor in small group activities with Korean peers}

In this section and the next, I show how Melody engaged in several forms of identity work to re-author herself as being competent as a biology student and active as a classroom participant. Melody and a few Korean girls sat close to each other and formed a group when asked to complete group tasks (e.g., laboratory activities). This group seemed to provide a safe and enjoyable learning environment in which Melody could speak without reservation and without needing to monitor her own speech. All members of the group primarily spoke in Korean, talked about pop culture that Korean students were commonly interested in (e.g., K-pop or Japanese anime), asked each other questions about class topics, complained about the class and teacher, and generally received support and comfort from each other. When students in this group made mistakes during lab activities, they made fun of or teased each other in a playful way.

A selected episode that occurred during a small group activity illustrates how Melody and her Korean friends engaged in building a safe and enjoyable learning environment for themselves. In this activity, students had to build a DNA transcription model using pop beads and to fill out a worksheet. After completion of these tasks, Ms. Davis orally tested each group. Melody worked with Jiyeon, Heejin, Eunmi, and Jasmine, all of whom were Korean transnational students. The following is a short snippet of their conversation as they started to fill out the worksheet. 


\begin{tabular}{|c|c|c|c|}
\hline & & & English translation $^{8}$ \\
\hline 1 & Eunmi: & Transcription 'eun' & Transcription is, \\
\hline 2 & Melody: & DNA and RNA. DNA for sure. & \\
\hline 3 & Eunmi: & 'geulae.' & That's right. \\
\hline 4 & Jiyeon: & For sure? & \\
\hline 5 & Melody: & For sure. & \\
\hline 6 & Jiyeon: & Sure. & \\
\hline 7 & Jasmine: & $\left(*^{* *}\right)$ talking about the types. & \\
\hline 8 & Eunmi: & mRNA, tRNA. & \\
\hline 9 & Melody: & Any, any type, $(* * *)$ & \\
\hline 10 & Eunmi: & 'a majda.' & Oh, that's right. \\
\hline 11 & Jasmine: & That's for RNA. & \\
\hline 12 & Jiyeon: & Definition? & \\
\hline 13 & Eunmi: & DNA & \\
\hline 14 & Jiyeon: & Transcription is, 'a majda' Any type $\left(^{* * *}\right)$ & $\begin{array}{l}\text { Transcription is, yeah, that's } \\
\left.\text { right, any type }{ }^{(* *}\right)\end{array}$ \\
\hline 15 & Melody: & Any type making RNA? & \\
\hline 16 & Eunmi: & Transcription 'eun', $\left(^{* * *}\right)$ making & Transcription is $\left(^{* * *}\right)$ making \\
\hline 17 & Jiyeon: & $\begin{array}{l}\text { ((Eunmi reads the text from the worksheet)) 'geulae geuleogo } \\
\text { bonikka' ((Melody laughs)) Making RNA 'sseo geunyang.' }\end{array}$ & $\begin{array}{l}\text { Right, that's right. Making } \\
\text { RNA, just write it. }\end{array}$ \\
\hline 18 & Eunmi: & Making RNA. & \\
\hline 19 & Melody: & 'ya, neo Jasmin hante wae geulae daeche' & $\begin{array}{l}\text { Hey, why do you act like } \\
\text { that to Jasmine? }\end{array}$ \\
\hline 20 & Jiyeon: & 'eotteohge?' & Like what? \\
\hline 21 & Melody: & 'Jasmine hage naebdwo geunyang.' & $\begin{array}{l}\text { Just let Jasmine do [what } \\
\text { she wants to do]. }\end{array}$ \\
\hline
\end{tabular}

In this segment, the students were trying to understand the questions on the lab worksheet and to negotiate the answers to the questions. They needed to find the definition of transcription and what types of DNA and RNA were involved in the process of transcription. They worked collaboratively to produce the answers. Eunmi first started to compose an answer by saying, "Transcription is" (Line 1) and Melody attempted to complete her sentence by saying, "DNA and RNA" (Line 2). Then, Jasmine said that they also needed to specify the types of RNA involved in the transcription process (Line 7). To respond to Jasmine's remark, Eunmi named the types of RNA, "mRNA, tRNA" (Line 8). Shortly after, Melody argued that transcription results in "any type of RNA" (Line 9). Jasmine said, "That's for RNA" (Line 11), implying that they were still missing some information needed to answer the particular question. However, Jiyeon, Eunmi, and Melody thought that the different types of RNA did not have to be discussed for this question, but that transcription was simply making "any type" of RNA from DNA. Jiyeon, in a slightly annoyed tone of voice, said, "Making RNA, just write it" (Line 17) to Jasmine, who was writing the answers on the group's worksheet. In response to Jiyeon's somewhat aggressive remark, Melody backed up Jasmine (Line 19, 21) by saying, "Just let Jasmine do what she wants to do."

As their conversation proceeded, Jasmine worked on the worksheet and other students built the DNA transcription model with the beads. Jasmine sometimes 
interrupted to advise the other group members on what should be shown in the model and urged them to complete the model building quickly. In this group, Jasmine was usually positioned as the most knowledgeable student as she tended to perform well and was positioned as an authority figure who knew more biology content than the other members of the group. On this particular day, she was the one leading the sub-activity of filling out the worksheet. The other students were followers who built the model using the beads and by following Jasmine's instructions. Certainly, the group dynamics were not equally balanced in terms of intellectual authority (e.g., who owns the knowledge, who makes the final decision on answers for the worksheet questions, and who does more intellectual parts of the task as opposed to simpler manipulation) as Jasmine was seen the intellectual authority of the group. Nonetheless, other students (Melody, Eunmi, and Jiyeon) actively sought information, suggested answers, and argued for their positions. In the same regard, although Melody gave up and yielded the intellectual authority to Jasmine, she was outspoken in positioning Jasmine as a knowledge authority while positioning herself and others as followers in this particular moment.

In this episode, the girls' engagement in academic discussion and play were highly intertwined. They discussed biology topics, joked around with each other, worked on model building, and talked about pop culture. The switches among these different subactivities were rapid and seamless. For instance, in this episode, when the three girls (Melody, Jiyeon, and Eunmi) found that someone had made a mistake, they made fun of the person by saying, "Stupid, you idiot," in a very playful manner. No single person was consistently positioned as being "stupid," but all three asserted that the others were stupid in different moments throughout the interaction. When they made a mistake, they did not seem to be embarrassed, but resisted the positioning of being stupid. It appeared as if they were engaged in a fun game of making fun of each other. They also often talked about their shared interests, such as Korean TV shows and pop songs, and even sang Korean songs quietly. Later on during this day when they had to figure out which nucleobase of RNA corresponded to each nucleobase of DNA, the girls argued intensely with each other. To support her answer, Melody asserted in a confident tone of voice "I took a note. You want to see it?" and added, "Are you looking down on me now?" Again, this example shows that the discourses employed for being academic and for having fun were tightly intertwined and switched seamlessly when the girls were allowed to employ both English and Korean.

At other times, they also supported each other's learning and encouraged the participation of all members of the group. The video revealed that throughout this activity, Heejin was mostly quiet and did not seem to participate. However, after they figured out how to build the model, Melody tried to pull Heejin into the model-building activity by saying, "Hey, Heejin, make [the model]" in a soft and inviting tone. Toward the end of this group activity, they collaboratively prepared for the oral quiz. Heejin asked for help from other group members by saying, "I don't know anything. What should I do? Hey, hurry up and teach me," in an urgent tone of voice. With this question as an invitation, the four students (Melody, Eunmi, Jiyeon, and Heejin) started to review their notes. Jiyeon then took up the role of leader and taught the other students by referring to her class notes. The other students (Heejin, Melody, and Eunmi) asked questions of each other and helped each other learn the content in preparation for their oral quiz. 
This analysis shows that Melody engaged in group activities with her close friends in a different way than she did in groups with unfamiliar classmates. In a group with her Korean friends, who shared her ethnicity and language, provided a learning environment in which Melody enjoyed learning, experienced a sense of community, and expressed authentic engagement with the content. I argue that being in a group with Korean speaking friends provided Melody the resources she needed to negotiate the classroom and school contexts in which newcomers were generally marginalized and English learning and network building were challenging. In this group with Korean-speaking peers, Melody and other Korean transnational students appeared to maximize what Bruna (2010) referred to as transnational social capital. Melody and other students in this group developed a sense of community based on shared language, ethnicity, and experiences as racial and linguistic minorities, English learners, and Koreans. They also showed evidence of developing emerging bilingual skills by blending the two languages to meet their needs. In this small group, students seemed to utilize these resources to support their own and others' learning to be successful in the class. In this setting, Melody crafted opportunities to pursue her questions, have fun with other students, and argue while not being intimidated. In this way, Melody negotiated her identity as an active and contributing group member and an engaged biology learner.

\section{A cooperative, attentive, and quiet participant}

In addition to her participation in group practices with Korean speaking students, a close analysis of the classroom video recordings suggested Melody also recognized opportunities for participating in class and connecting with a broader group of peers and her teacher. Herein, I present several examples of how she crafted her own ways of participating and negotiating her identities at the biology classroom level.

In the class, Ms. Davis often asked for students to volunteer to return graded homework assignments and worksheets to their peers. When Ms. Davis called students' names and asked them to pass out the worksheets, some students refused to do so because they did not know the other students' names. ${ }^{9}$ Frustrated by this response, Ms. Davis would ask, "Who knows names? Pass out the papers," or even simply asked, "Who knows names?" while holding a stack of graded worksheets in her hand. In these situations, it was mostly students who had built a substantial and trusting relationship with Ms. Davis, by asking and answering questions and interacting with her, who volunteered to help her in distributing the worksheets. One day, Melody volunteered to return the papers although she was not one of those students who had developed a comfortable relationship with Ms. Davis (the interview analysis earlier showed this point).

On this day, when Ms. Davis first asked, "Who knows names?" Melody did not express her intention to pass out the papers. She appeared to be hesitant. However, when Ms. Davis passed by Melody, she looked back at Ms. Davis, raised her hand, and said, "I will try." By saying, "I will try," Melody conveyed the message that although she did not "know names" she would try to identify students and return their worksheets. Melody negotiated and chose to be a student who readily volunteers to help the teacher, interacts with the teacher, and interacts with unfamiliar classmates by handing out their worksheets. On another day, Melody volunteered 
once again to pass out students' graded work. Interestingly, before she responded to Ms. Davis's call for volunteers, she first said, "I will do it, too," in Korean, letting her Korean friends know that she was going to volunteer to help Ms. Davis. A few seconds later, when Ms. Davis came closer to her, Melody raised her hand to get the teacher's attention, and Jiyeon, who had heard Melody say, "I will do, too," made eye contact with Ms. Davis and pointed her fingers at Melody to help Melody's intention be noticed by the teacher. In this episode, Melody's saying, "I will do it, too," was a way for her to facilitate the negotiation of her identities because she had constructed an identity that did not match with what she was trying to do at this moment. Because it was unexpected behavior for Melody to pass out graded worksheets, she might have thought that she needed to be conditional ("I will try") rather than certain or needed a preliminary ("I will do it, too") to let peers know about her unexpected behavior and to have their support.

Indeed, Ms. Davis recognized Melody's attempts to negotiate and navigate new possible identities and responded to her attempt in an encouraging way. When Melody volunteered to pass out the graded worksheets, Ms. Davis responded, "You will try. Thank you." In addition, on this same day, Melody and Ms. Davis had several exchanges during the lecture, which was unusual. For instance, Melody answered Ms. Davis's questions, and Ms. Davis acknowledged her answers and, during this class, Ms. Davis mentioned Melody in one of her instructional narratives, by using Melody's name in an analogy. By volunteering to pass out the graded worksheets, Melody first opened the possibility of new actions in which she did not usually engage and also showed to Ms. Davis that she was willing to negotiate a new identity. In response to her negotiation, Ms. Davis provided opportunities for her to discursively enact the new identity as a student who tries a new challenge, responds to the teacher's question, and establishes a trusting relationship with the teacher.

As the school year proceeded, Melody enacted a series of attempts to perform her new identity as a participatory student and as she did so, the teacher's reactions to her attempts occurred on more often. In the second half of the school year, my field notes and the student utterance map indicated Melody participated in whole class discussion more often than before. Sometimes her voice was almost inaudible, but she visibly nodded or shook her head as a response to several yesor-no questions from Ms. Davis, and loudly laughed and even gestured when students made humorous comments. In addition, Melody often quietly asked Jiyeon, who was sitting next to her, curricular topic-related questions in Korean when she did not understand Ms. Davis' explanations. One day, when Ms. Davis asked a question, Melody made a face indicating she was trying to come up with the answer but could not think of it at the moment. Ms. Davis recognized her engagement and said, "Melody, you are thinking." Upon this remark, many students turned to look at Melody. In this episode, Melody agentively negotiated identities as an engaged biology student, and Ms. Davis recognized her negotiation and indexed her as a cooperative, engaged class participant. Although Melody did not speak as loudly or clearly enough to be heard during whole class discourse, she crafted her own ways of interacting with Ms. Davis, communicating her ideas, and negotiating her identities. 
Had those exchanges and interactions between Ms. Davis and Melody occurred more often and sooner during the school year, I believe that this episode and other episodes capturing her participation might have facilitated the construction of her new identity as an engaged biology student who participates in the class discussion, cares about the class, and is an active member. As Wortham (2006) argues, for an individual's ways of doing to become an identity, surrounding people must recognize the pattern and the recognition should be repeated multiple times across interactional events. Unfortunately, however, these kinds of episodes did not happen frequently enough, and then Ms. Davis left the classroom when she went on maternity leave. When the new substitute teacher was introduced to the class, Melody had to navigate and negotiate different tensions and challenges, and thus similar ways for her participation were no longer observed.

\section{Discussion and Implications}

In this study, I have shown the lived experiences of Melody, a transnational Korean girl from a gireogi family in an AP Biology class in a high school in the US, including linguistic and racial marginalization at the school and challenges that she faced in building social networks with a broad group of peers. This study shows that these challenges are not simply social and emotional but have critical implications for identity construction, science classroom participation, and learning. In particular, an analysis of the ethnographic data demonstrates how the meso-level contexts of Parkview High and the AP Biology classroom did not facilitate but rather constrained opportunities for her to participate in and learn biology.

The findings indicate the importance of close analysis of meso-level contexts and personal contexts in understanding transnational students' science learning and identity construction. In particular, Melody's experiences were unique because of her gireogi family background. As a gireogi mother, Melody's mother felt marginalized and discouraged and lacked the practical and symbolic resources (e.g., informational resources, social networks) to sufficiently assist Melody's academic pursuit. Her mother, who experienced the same challenges of learning English and socializing with native English-speakers, understood that Melody would feel the same challenges and demoralization and chose not to push her enact practices that would sacrifice her daughter's emotional and psychological well-being.

Science teachers and education researchers often assume that an ethnic, linguistic, and/or racial group is homogeneous and its culture is static and essentialized, which obscures the differences attributable to, for instance, local situations, family backgrounds, and prior experiences. The focus on the various dimensions of different contexts help individual differences to be seen in the ways in which people make sense of various environments and speak, act, and interact with surrounding people. Although Melody was challenged, she agentively negotiated with the contexts and her identities. She resisted the label as a FOB in the interviews with me, crafted and participated in a safe and comfortable learning environment by utilizing her transnational social capital, and found ways to interact with classmates and with Ms. Davis.

It is noteworthy that Melody tried to both create a space that is safer and temporarily conducive to her engagement, learning, and meeting social-emotional needs as well as seeking out newer and broader networks that could perhaps help her in the future to 
learn the course content and re-figure her identities. Often, students who form a peer group with others from their own racial and linguistic group are evaluated negatively for their lack of efforts to integrate and learn and, thus, are marked as passive and reserved. I argue that such social interactional patterns should be understood from the participants' sense-making and agentive negotiation of the contexts. Rather than pushing those students to reach out of their co-ethnic and linguistic groups, we should first ask why they have made such choices; what opportunities are afforded in their co-ethnic and racial groups that other peer groups do not afford; and how students' peer groups can provide an environment conducive to racial and linguistic minority students' intellectual engagement, participation, learning, and identity construction.

Based on the findings of the study, I offer several implications for research, teacher education and policy, and classroom practice. First, I call for more in-depth studies that examine transnational students in science learning contexts. Public media, teachers and administrators, and research have long assumed the homogeneity of Asian students and their high performance in school and school science. While collectively referred to as Asian, there is a wide range of differences among them in terms of ethnicity, language, gender, socioeconomic backgrounds (both before and after transnational migration), and motivations for migration. In addition, there are differences with regards to the kinds of social and cultural capital they bring with them from their home countries. In particular, the educational migration commonly practiced by Koreans, Chinese, and Taiwanese and the migration of Southeast Asians in search of political freedom and economic and educational opportunities are born from different circumstances and these families experiences may be quite different from one another. More studies are needed to understand transnational students' lived experiences of science learning, classroom participation, and identity construction. The research should pursue nuanced understandings of these individual students' science learning by focusing on local contexts and family backgrounds that offer different kinds of affordances and constraints.

Second, in order to suggest implications for teacher education and policy, I reiterate that the science classroom is not a culturally and socially neutral place as is often assumed. While various pieces of cultural, local, and youth knowledge are brought to bear to the classroom, some pieces of knowledge shared by certain cultural groups are capitalized on more often than others during classroom discourses. This is due in large part because teachers in most countries represent the mainstream cultural and linguistic groups and immigrants will not likely find their knowledge and experiences reflected by their teacher. In the US, this is even less likely in math and science classrooms where racial and linguistic minorities are underrepresented in science and mathematics teacher education programs. In addition, it is important to note that participating in science classroom discourse is not only cognitive, but it also involves identity work. By participating in a classroom in various ways, students perform, construct, and negotiate their identities. As shown in this study, when the classroom is racially and linguistically diverse, social dynamics become even more complex because of inter-racial and linguistic conflicts and stratification. This implies that conversations around science content can become even more difficult for transnational students to navigate. 
The first step in addressing these issues in teacher education, in particular for teachers who (will) teach in racially and linguistically diverse classrooms, is to encourage science teachers to reflect on their own teaching and student learning-pondering how culture and cultural knowledge play out in their own class, what social relationships and networks are established among students and between students and the teacher, and how those cultural and social aspects may constrain some students' access to participation and resources for learning science. I often observe science teacher education efforts that, with a good intention, encourage pre-service teachers to draw on students' experiences to bridge between science and students' everyday knowledge and experiences. As Bruna (2009) reminds us, such everyday connection presented by a teacher is still under "teacher control" that determines which everyday knowledge and practices are appreciated. We should reconsider such approaches. Rather, science teachers should be trained to acknowledge and appreciate students' crafted negotiation, such as what Melody showed, and to capitalize on it.

Teachers should also be trained to notice identity models circulating among students, such as narratives about certain ethnic and immigrant groups (e.g., Asian immigrants speak English poorly or they do not want to learn English) and/or regarding who can and cannot do science (e.g., only smart people can do science, English learners do not have anything to contribute to science learning), and how those can impact students' classroom participation and learning. For instance, several science teachers at Parkview High, including Ms. Davis, said that they were not aware of or attentive to racial and linguistic divide among students. Teachers can learn about these identity models through the means of student interviews, surveys, and/or ethnographic investigation (Martin et al. 2013). School administrators, staff, and counselors who interact with students more closely, should support teachers to learn about their students. Recruiting faculty and staff members from non-dominant racial and linguistic backgrounds would also help offering different and new insights into how to effectively support a diverse student body.

Additionally, I would like to draw attention to Melody's personal contexts, in particular her family contexts as a gireogi family. Her mother felt marginalized and was demoralized. The sources from which her mother could gain information for her children's education were limited. Schools should support transnational parents and families, especially those from low socioeconomic classes by providing adequate information for children's education, having the parents and family be involved in various school activities, and eventually helping them to be empowered to support their children's learning in school. Schools should appreciate students' parents as stakeholders in their education who care about and contribute to their children's learning. Bringing parents from diverse racial and linguistic groups together may help them to initiate a conversation across racial and linguistic borders. Hiring school counselors from the same racial and linguistic groups as the students could also help parents to feel less intimidated and more supported.

In terms of the science classroom practices, I would like to draw to several recent research studies. For instance, Carlone et al. (2014) show that when teachers implement practices that value different forms of doing science (e.g., generating ideas, imagination, drawing on individual students' experiences and intuition), new identity models can emerge that enhance students' equitable participation and 
access to the learning resources. Along the same line, I suggest that teachers should provide classroom practices that can facilitate the emergence of new narratives about what competent science students and classroom participation mean and what are the authorized languages for engaging in classroom discourses. In addition, teachers also need to carefully attend to and recognize students' negotiation of contexts and identities. Individual students' identity work can be subtle and vary depending on students and thus may not be easy to recognize. The field of science education has encouraged teachers to appreciate knowledge and ideas that students bring to the class and build on these (Calabrese Barton and Tan 2009; Hammer et al. 2012). This requires teachers to be responsive to students' thinking and provide opportunities to explore and negotiate their ideas. I argue that the same effort should be made with respect to students' identity work. For instance, science teachers' attention should be focused on how individual students identify each other, how they negotiate identities in order to be recognized as a particular kind of class member, and how the patchwork of multiple students' identity work impacts individual students' participation in and learning of science. When these are recognized, teachers should capitalize on individual students' agentive negotiation and provide more opportunities for re-figuring identities.

Finally, this study also provides critical implications for education practices and research in sending countries, such as Korea, China, and Taiwan. As the number of families being separated by educational migration increases, there need to be more research studies documenting the challenges these families face, including the potential for negative impact on marriages and strains on relationships in families. In addition, more research is needed to explain the cause for the wide spread of educational migrations. Finally, I point out that little is known about students' lived experiences, learning, and moment-by-moment negotiations of identities relative to ethnicity, language, and learning. As an agent and stakeholder of their own education, students should be more closely studied. For instance, why do they choose to pursue education in Englishspeaking countries? How do they make sense of new learning environments? How do they negotiate and craft new identities and opportunities for learning? What are the trajectories of these transnational students after their K-12 education? How, as a result of their own experiences, do they perceive racial and linguistic minorities in their home countries? In particular, I raise critical questions about how educational policy and practices may tacitly encourage students and parents to pursue educational migration and how these policies contribute to educational inequity among people in the sending countries while reproducing the hegemony of English language and cultural norms and education systems of a few English-speaking countries. We should turn this wide spread of educational migration into an opportunity for making new possibilities for equity instead of reproducing existing inequity. Perhaps, educators in sending countries should prepare for students to question critically about, rather than conform to, the hegemony of English and educational practices in English-speaking countries. We should encourage students, from their experiences of learning and living in new countries, to construct their new identities and perspectives that support equitable education and society. A better and close understanding of transnational migration students may help us think how to achieve the goal of educational equity both locally and globally. 


\section{Conclusion}

Increasingly more Asian students migrate to and settle in the US or different countries than their birth place in pursuit of new opportunities. While the model minority stereotype is commonly cited when discussing Asian transnational students' education, many students face serious social, emotional, and academic challenges, and their needs are not met. Perhaps because of the stereotype and other kinds of identity models prevalent both in sending and receiving countries, stories of individual students and their lived experiences are not often heard. The story of Melody's biology learning and identity work provides an insight into what transnational students' experiences of schooling and science learning may look like. As a science education community, we need more studies investigating and understanding students like Melody. We also need more studies that approach these students' science learning experiences from multiple perspectives that incorporate cognitive, affective, and social dimensions of learning. With nuanced understandings of these students, we will be able to better support students' science learning and contribute to equity in education, both in their sending and receiving countries.

\section{Endnotes}

${ }^{1}$ In this paper, I use Revised Romanization to transliterate Korean into English. For more information about this system, please visit http://www.korean.go.kr/front_eng/ roman/roman_01.do.

${ }^{2}$ Advanced Placement (AP) is a program in the United States and Canada that offers college-level curricula and examinations to high school students. Students who obtain high scores on AP exams may receive course credit for the subject matter (ie., Biology or Calculus) at colleges or universities.

${ }^{3}$ Morawska (2001) defines transnationalism as extended engagement in "civic-political membership, economic involvements, social networks, and cultural identities that link people and institutions in two or more nation-states in diverse, multilayered patterns" (p. 175). The migration and family separation of gireogi families engage in transnational exchanges of diverse forms of resources (e.g., economic value, cultural and social capital) and consequently contibute to emerging transnational ideologies. Although I acknowledge the ongoing debate about what counts as transnationalism, this is not the main focus of this paper. For more theoretical discussions, see Morawska (2003) and Portes et al. (1999).

${ }^{4}$ I adopted the labels used by the Public School system in which Parkview High was housed.

${ }^{5}$ In order to focus on Melody's sense-making of the contexts, I do not present the details of the findings from these analyses. For more detailes, see Ryu (2014) and Ryu (2015).

${ }^{6}$ The use of the terms FOB and Twinkie to categorize Asian immigrants is reported in several studies (e.g., Reyes 2007; Talmy 2004). While in some other studies (e.g., Reyes 2007) people pronounced each letter of FOB individually (i.e., /ef-o-bi/), all participants in this study pronounced it as one work (i.e., /fa:b/). Often, students also used its derivative form, FOBby, which suggests a shared and entrenched identity model of FOBs at Parkview High. For more details, see Ryu (2014).

${ }^{7}$ Utterances made in Korean have been translated into English and are italicized. 
${ }^{8}$ The transcription conventions: $(* * *)$ indicates inaudible words or phrases. Words and phrases spoken in Korean were romanized by Revised Romanization and encapsulated in a single quotation mark in the first column. When students mixed Korean and English in one utterance, the English translation was appended in the second column.

${ }^{9}$ This is another piece of evidence of students' racial and linguistic divide and lack of interactions across the groups.

\title{
Additional file
}

Additional file 1: Ryu_APSE_Executive Summary. (PDF $214 \mathrm{~kb}$ )

\begin{abstract}
About the Authors
Dr. Minjung Ryu is an Assistant Professor in the Department of Curriculum and Instruction and Chemistry at Purdue University where she teaches chemistry for pre-service elementary teachers and secondary science teaching methods courses. Her research interests include science learning, identity construction, and discursive participation in formal and informal science learning settings, particularly those of Asian transnational students in U.S. school settings. Currently, she conducts an after school project that engages Burmese refugee youth in critical STEM literacy practices.
\end{abstract}

Received: 5 October 2015 Accepted: 12 November 2015

Published online: 21 December 2015

\section{References}

Anderson, K. T. (2009). Applying positioning theory to the analysis of classroom interactions: mediating micro-identities, macro-kinds, and ideologies of knowing. Linguistics and Education, 20, 291-310.

Archer, L., Dewitt, J., Osborne, J., Dillon, J., Willis, B., \& Wong, B. (2010). "Doing" science versus "being" a scientist: examining 10/11-year-old schoolchildren's constructions of science through the lens of identity. Science Education, 94, 617-39.

Baker, C. D. (2002). Ethnomethodological analyses of interviews. In J. A. Holstein \& J. F. Gubrium (Eds.), Handbook of interview research (pp. 777-95). Thousand Oaks: Sage.

Bellocchi, A., \& Ritchie, S. M. (2011). Investigating and theorizing discourse during analogy writing in chemistry. Journal of Research in Science Teaching, 48(7), 771-92.

Brickhouse, N. W., \& Potter, J. T. (2001). Young women's scientific identity formation in an urban context. Journal of Research in Science Teaching, 38(8), 965-80.

Brown, B. A., Reveles, J. M., \& Kelly, G. J. (2005). Scientific literacy and discursive identity: a theoretical framework for understanding science learning. Science Education, 89, 779-802.

Bruna, K. R. (2009). Jesús and María in the jungle: an essay on possibility and constraint in the third-shift third space. Cultural Studies of Science Education, 4(1), 221-37.

Bruna, K. R. (2010). Mexican immigrant transnational social capital and class transformation: examining the role of peer mediation in insurgent science. Cultural Studies of Science Education, 5(2), 383-422.

Bucholtz, M., \& Hall, K. (2005). Identity and interaction: a sociocultural linguistic approach. Discourse Studies, $7(4-5), 585-614$

Butler, J. (1990). Gender trouble. New York: Routledge.

Calabrese Barton, A., \& Tan, E. (2009). Funds of knowledge and discourses and hybrid space. Journal of Research in Science Teaching, 46(1), 50-73.

Calabrese Barton, A., Kang, H., Tan, E., O'Neil, T. B., Bautista-Guerra, J., \& Brecklin, C. (2013). Crafting a future in science: tracing middle school girls' identity work over time and space. American Educational Research Journal, 50(1), 37-75.

Campbell, K. K. (2005). Agency: promiscuous and protean. Communication and Critical/Cultural Studies, 2(1), 1-19.

Carlone, H. B., Scott, C. M., \& Lowder, C. (2014). Becoming (less) scientific: a longitudinal study of students' identity work from elementary to middle school science. Journal of Research in Science Teaching, 51(7), 836-69.

Chang, J. (2006). Globalization and English in Chinese higher education. World Englishes, 25(3-4), 513-25.

Cho, U. (2005). The encroachment of globalization into intimate life: the flexible Korean family in "economic crisis". Korea Journal, 45(3), 8-35.

Covarrubias, A., \& Liou, D. D. (2014). Asian American education and income attainment in the era of post-racial America. Teachers College Record, 116(6), 1-38.

Derry, S. J., Pea, R. D., Barron, B., Engle, R. A., Erickson, F., Goldman, R., et al. (2010). Conducting video research in the learning sciences: guidance on selection, analysis, technology, and ethics. The Journal of the Learning Sciences, 19(3), 3-53.

Duranti, A. (2004). Agency in language. In A. Duranti (Ed.), A companion to linguistic anthropology (pp. 451-73). Malden: Blackwell.

Finch, J., \& Kim, S.-k. (2012). Gireogi families in the US: transnational migration and education. Journal of Ethnic and Migration Studies, 38(3), 485-506.

Goodwin, C., \& Duranti, A. (1992). Rethinking context: an introduction. In A. Duranti \& C. Goodwin (Eds.), Rethinking context: language as an interactive phenomenon (pp. 1-42). New York: Cambridge University Press.

Guo, Y., \& Beckett, G. H. (2007). The hegemony of English as a global language: reclaiming local knowledge and culture in China. Convergence, 40(1/2), 117. 
Hammer, D., Goldberg, F., \& Fargason, S. (2012). Responsive teaching and the beginnings of energy in a third grade classroom. Review of Science, Mathematics and ICT Education, 6(1), 51-72.

Holland, D., Lachicotte, W., Jr., Skinner, D., \& Cain, C. (1998). Identity and agency in cultural worlds. Cambridge: Harvard University Press.

Huang, S., \& Yeoh, B. S. (2005). Transnational families and their children's education: China's 'study mothers' in Singapore. Global networks, 5(4), 379-400.

Kahveci, A., Southerland, S. A., \& Gilmer, P. J. (2008). From marginality to ligitimate peripherality: understanding the essential functions of a women's program. Sicnece Education, 92, 33-64.

Kamberelis, G. (2001). Producing heteroglossic classroom (micro)cultures through hybrid discourse practice. Linguistics and Education, 12(1), 85-125.

Koo, H. (2007). The changing faces of inequality in South Korea in the age of globalization. Korean Studies, 31, 1-18

Kozoll, R. H., \& Osborne, M. D. (2004). Finding meaning in science: lifeworld, identity, and self. Science Education, 88, 157-81.

Lee, S. J. (2009). Unraveling the "model minority" stereotype: listening to Asian American youth (2nd ed.). New York: Teachers College Press.

Lee, H. (2010a). "I am a Gireogi Mother": education exodus and life transformation among Korean transnational women. Journal of Language, Identity, and Education, 9, 250-64.

Lee, J. (2010b). Ideologies of English in the South Korean" English immersion" debate. In Paper presented at the Selected Proceedings of the 2008 Second Language Research Forum.

Lew, J. (2006). Asian Americans in class: charting the achievement gap among Korean American youth. New York: Teachers College Press.

Malone, K. R., \& Barabino, G. (2009). Narrations of race in STEM research settings: identity formation and its discontents. Science Education, 93, 485-510.

Martin, S. N., Wassell, B., \& Scantlebury, K. (2013). Frameworks for examining the intersections of race, ethnicity, class, and gender on English language learners in K-12 science education in the USA. In J. A. Bianchini, V. L. Akerson, A. Calabrese Barton, O. Lee, \& A. J. Rodriquez (Eds.), Moving the equity agenda forward: equity research, practice, and policy in science education (pp. 81-98). New York: Springer.

Morawska, E. (2001). Immigrants, transnationalism, and ethnicization: a comparison of this great wave and the last. In G. Gerstle \& J. Mollenkopf (Eds.), E pluribus unum? Comtemporary and historical perspectives on immigrant political incorporation (pp. 175-212). New York: Russell Sage.

Morawska, E. (2003). Disciplinary agendas and analytic strategies of research on immigrant transnationalism: challenges of interdisciplinary knowledge. International Migration Review, 37(3), 611-40.

Ochs, E. (1993). Constructing social identity: a language socialization perspective. Research on Language and Social Interaction, 26(3), 287-306.

Olitsky, S. (2007). Facilitating identity formation, group membership, and learning in science classrooms: what can be learned from out-of-field teaching in an urban school? Science Education, 91(2), 201-21.

Paik, S. J., Kula, S. M., Saito, L. E., Rahman, Z., \& Witenstein, M. A. (2014). Historical perspectives on diverse Asian American communities: immigration, incorporation, and education. Teachers College Record, 116(8), 1-45.

Park, J.-K. (2009). 'English fever' in South Korea: its history and symptoms. English Today 97, 25(1), 50-7.

Pew Research Center. (2012). The rise of Asian Americans. Retrieved from http://www.pewsocialtrends.org/2012/06/19/ the-rise-of-asian-americans/.

Portes, A., \& Zhou, M. (2012). Transnationalism and development: Mexican and Chinese immigrant organizations in the United States. Population and Development Review, 38(2), 191-220.

Portes, A., Guarnizo, L. E., \& Landolt, P. (1999). The study of transnationalism: pitfalls and promise of an emergent research field. Ethnic and Racial Studies, 22(2), 217-37.

Rahm J, Moore JC. A case study of long-term engagement and identity-in-practice: Insights into the STEM pathways of four underrepresented youths. Journal of Research in Science Teaching. 2015. doi: 10.1002/tea.21268

Reda, M. M. (2009). Between speaking and silence: a study of quiet students. Albany: State University of New York.

Reyes, A. (2007). Language, identity, and stereotype among Southeast Asian American youth: the other Asian. Mahwah: Lawrence Erlbaum.

Ryu, M. (2013). "But at school... I became a bit shy": Korean immigrant adolescents' discursive participation in science classrooms. Cultural Studies of Science Education, 8(3), 649-71.

Ryu, M. (2014). Korean immigrant high school students' identities and their impact on school learning. In P. G. Min \& S. Noh (Eds.), Second-generation Korean experiences in the United States (pp. 205-24). Lanham: Lexington Books.

Ryu, M. (2015). Positionings of racial, ethnic, and linguistic minority students in high school biology class: implications for science education in diverse classrooms. Journal of Research in Science Teaching, 52(3), 347-70.

Shin, S. H., Choi, H., \& Kim, M. J. (2014). Mental distress of children in gireogi families. Journal of Korean Academy of Psychiatric and Mental Health Nursing, 23(4), 208-16.

Smith, B., \& Sparkes, A. C. (2008). Contrasting perspectives on narrating selves and identities: an invitation to dialogue. Qualitative Research, 8(1), 5-35.

Spencer, M. B. (1999). Social and cultural influences on school adjustment: the application of an identity-focused cultural ecological perspective. Educational Psychologist, 34(1), 43-57.

Talmy, S. (2004). Forever FOB: the cultural production of ESL in the high school. Pragmatics, 14(2/3), 149-72.

Trytten, D. A., Lowe, A. W., \& Walden, S. E. (2012). "Asians are good at math. What an awful stereotype": the model minority stereotype's impact on Asian American engineering students. Journal of Engineering Education, 101(3), 439-67.

van Manen, M. (1990). Researching lived experience: human science for an action sensitive pedagogy. Albany: State University of New York Press.

Waters, J. L. (2012). Geographies of international education: mobilities and the reproduction of social (dis)advantage. Geography Compass, 6(3), 123-36.

Wetherell, M. (2007). A step too far: discursive psychology, linguistic ethnography and questions of identity. Journal of Sociolinguistics, 11(5), 661-81. 
Wiley, T. G., \& Lukes, M. (1996). English-only and standard English ideologies in the U.S. TESOL Quarterly, 30(3), 511-35. Wortham, S. E. F. (2006). Learning identity: the joint emergence of social identification and academic learning. New York: Cambridge University Press.

Yeh, C. (2003). Age, acculturation, cultural adjustment, and mental health symptons of Chinese, Korean, and Japanese immigrant youths. Cultural Diversity and Ethnic Minority Psychology, 9(1), 34-8.

Yin, R. K. (2003). Case study research design and methods (3rd ed.). Thousand Oaks: Sage.

Yoon, B., Simpson, A., \& Haag, C. (2010). Assimilation ideology: critically examining underlying messages in multicultural literature. Journal of Adolescent \& Adult Literacy, 54(2), 109-18.

\section{Submit your manuscript to a SpringerOpen ${ }^{\circ}$ journal and benefit from:}

- Convenient online submission

- Rigorous peer review

- Immediate publication on acceptance

- Open access: articles freely available online

- High visibility within the field

- Retaining the copyright to your article

Submit your next manuscript at $\boldsymbol{\nabla}$ springeropen.com 